Humeniuk Volodymyr, Doctor of Science in Economics, Professor of Tourism Department, Ivano-Frankivsk National Technical University of Oil and Gas ORCID: 0000-0002-8493-4470 Web of Science ResearcherID N-9466-2017

Shtan Maryna, Ph.D., Associate Professor of Department of Finance, Accounting and Fundamental Economic Disciplines,

National Academy of Management, Ukraine, Kyiv

ORCID: 0000-0002-4938-555X

\title{
CONCEPTS OF REGULATION OF RESORT AND RECREATIONAL SERVICES PRICING IN THE CONDITIONS OF GLOBALIZATION
}

The article deals with general theoretical, methodological and practical aspects of state regulation of pricing for resort and recreational services. The list of factors that need to be taken into account in the development of the state pricing policy in the market of resort and recreational services in the context of global trends in tourism developmentwas presented. Conceptual approaches to value identification of resort and recreational services for the consumer are revealed. The extent of asymmetry of consumer spending on wellness tourism in European countries has been revealed. The modern practice of state regulation of pricing for resort and recreation services is analyzed. The perspective directions of modernization of the state pricing policy for resort and recreation services are outlined. The materials of the conducted research can be used to develop the methodological base of state regulation of pricing in the resort and recreational sphere.

Keywords: globalization, state regulation of pricing, resort and recreational services, tourism.

Гуменюк Володимир, Штан Марина. Концепції регулювання ціноутворення на курортно-рекреаційні послуги в умовах глобалізації.

У статті розглядаються загальнотеоретичні, методологічні й практичні аспекти державного регулювання цінотворення на курортно-рекреаційні послуги. Наведено перелік чинників, щяо потребують врахування при розробиі 
державної иінової політики на ринку курортно-рекреаційних послуг в умовах глобальних тенденцій розвитку туризму. Розкрито концептуальні підходи до ціннісної ідентифікації курортно-рекреаџійних послуг для споживача. Виявлено масштаби асиметрії витрат споживачів на велнес-туризм у європейських країнах. Проаналізовано сучасну практику державного регулювання иіноутворення на курортно-рекреаційні послуги. Окреслено перспективні напрями модернізаиіі державної політики ціноутворення на курортно-рекреаційні послуги. Матеріали проведеного дослідження можуть бути використані для розвитку методологічної бази державного регулювання иіноутворення в курортно-рекреаиійні cpepi.

Ключові слова: глобалізація, державне регулювання ціноутворення, курортно-рекреаційні послуги, туризм.

Relevance of the research topic. Global trends in tourism development represent a positive trend in demand for resort and recreational services. In the global economy, the average annual growth rate of total revenues from health tourism, since 2012 , was $6.8 \%$, reaching $\$ 563.2$ billion in 2015 ; they are projected to grow at an average annual rate of $7.5 \%$ to $\$ 808$ billion by 2020 . About $1 / 6$ of all domestic and international travel costs are for resort and recreational services. In Ukraine, their growth potential is estimated to be three to seven times that of the EU countries. In terms of concentration of natural healing resources, Ukraine is one of the richest European countries, revealing a powerful potential for economic growth, enhancing the domestic market of resort and recreational services and a competitive breakthrough in international tourism. The direct contribution of the resort and recreation sphere to the formation of GDP in European countries differs in the range from $0.4 \%$ to $9.5 \%$, in Ukraine it does not exceed $1.0 \%$, although under the optimistic scenario by 2026 , combined with the indirect $(1,8 \%)$ and induced $(0.7 \%)$ contributions will be $3.8 \%$ of GDP $[2 ; 13 ; 15]$.

The development of the market of resort and recreational services will provide a multifaceted contribution to the formation of the national wealth of the country: investment in human capital, created jobs, financial flows of wages, social transfers, taxes, rent. It is linked to the human development and health of the nation, strengthening the financial base of local government, improving the well-being of the population, taking into account the multiplier effect of employment, income, investment and innovation. In view of these factors, the issue of research of perspective directions of modernization of state regulation of pricing for resort and recreational services in the conditions of global tendencies of tourism development becomes especially urgent $[4, \mathrm{p} .418]$.

Formulation of the problem. The processes of globalization and the widespread use of information and communication technologies have created new opportunities for the development of the resort and recreational sphere. Factors such as 
high costs of acquiring medical services in high-tech countries, increasing public needs for restoring public health, the inability of state, municipal, medical and insurance institutions to provide human capital reproduction in order to fund social guarantees, projects and initiatives that consumers have begun to look for more effective ways to meet solvent demand, given the opportunity to receive treatment in less costly countries with higher quality services, more affordable prices and so on.

At the same time, the complexity of the state's pricing policy in the resort and recreation sphere is caused by many internal socio-economic problems of social development. The contemporary demands of Ukrainian society place the highest priority on national security, the promotion of the health of the nation, the improvement of the quality of life, and the proper level of reproduction of human capital.

In Ukraine, the problem of forming an effective pricing policy of the state in the resort and recreation sphere has arisen as extremely complicated due to the low level of social security of treatment and rehabilitation of the population from public consumption funds, the difficulties of market interaction due to the risks of reducing the purchasing power of the population and low competitiveness of resort and recreational services.

Analysis of recent research and publications. Modern economic literature presents scientific developments of foreign and domestic scientists that reveal different aspects of pricing. The issues of state regulation of pricing in the transformational economy were developed by I. Chernysh [1], A. Mazaraki, V. Lagutin [6], S. Melnichenko [7], O. Tishchenko [14], N. Ushenko [16], and other scientists. However, the problems of forming an effective domestic market of resort and recreational services of Ukraine, expanding the possibilities of restoring the health of the population, developing the competitiveness of national resorts to attract foreign consumers, revitalizing inbound tourist flows in the Ukraine requires the development of a state pricing policy for resort and recreational services in the context of global trends in tourism development.

Presenting main material. Structural and institutional transformations in the market of resort and recreational services and the need for systematic changes in the modernization of the mechanism of state regulation of resorts and tourism are caused by the development of processes of globalization, international competition, and internationalization of business. The main factors that need to be taken into account when developing the state's pricing policy in the market of recreational services in the context of global trends in tourism development include:

1) significant differences in prices for medical services, accommodation, food and recreation in the world allow countries to specialize and take advantage of comparative competitive advantages in the world market; 
2) creation and dissemination of international standards, unification of technologies, procedures and conditions for the provision of resort and recreational services;

3) availability of an international comparative system for training specialists and conditions for obtaining certificates and licenses for professional practice;

4) development of the private sector of the resort and recreation sphere and creation of international transnational corporations (hotel chains, medical and nonmedical SPAs, health resorts, wellness centers) providing high quality services using transfer pricing technologies;

5) asymmetry of distribution of natural healing resources, development of resort and recreational and recreational infrastructure, tourist security, social accessibility of services;

6) differentiation of prices for labor and availability of different working conditions and its remuneration contributes to the international migration of specialists in medical, service and management profile.

7) excellent conditions for the formation of financial resources, the creation of added value, the generation of resort rent in different countries of the world.

8) differences in approaches to the identification of the value of health, tourism, recreation in different socio-economic formations, the role of state regulators in the formation of the price system, peculiarities of motivation and behavior of the consumer of tourist services, development of a system of value-oriented management in the resort and tourism sector of each countries in particular.

In the scientific intelligence of economists, until the twentieth century, the concept of value was not thoroughly conducted, since considerable attention was paid to the analysis of the economic category of value, which expresses the socially necessary labor and economic relations between the subjects of economic activity embodied in goods and servicesassociated with the processes of production and exchange, pricing, estimation of market parameters of domestic trade, international transactions, execution of commercial agreements, etc. [8, p. 898].

Given the increasing need for human capital reproduction, the focus is on the need for value-based identification of resort and recreational services that should be accessible to everyone who needs them, regardless of geographical, economic, social, cultural or ethnic characteristics. At the same time, the quality of services, including adequacy, safety, efficiency, effectiveness, timeliness, satisfaction of expectations and needs, process and result stability, continuous improvement and improvement, must be ensured for the proper reproduction of human capital.

With regard to the value that a person has gained as a result of consuming the services he offers, R. Woodruffand S. Gardial propose to determine the level of satisfaction of consumer needs. The formation of a positive or negative consumer perception depends on the situation, which is characterized by the specific conditions 
in which the services are created. The feeling can be expressed in the form of a direct reaction to the outlined service offer, as well as through full resonance in response to a series of similar empirical situations [17, p. 95-96].

In many cases, the quality of resort and recreational services is close to understanding their value to the consumer. However, in the search for personalized value, the consumer is faced with the need to choose a compromise set of services with certain quality and price characteristics.

Consumer value is determined by the necessary conditions and needs of the person, in connection with this resort and recreation services play the role of a transmitter in human life, contribute to the improvement of quality of life and human development.

The following basic approaches can be used in the recreational sphere to uncover the economic nature of value:

1) in relation to consumers of resort and recreational services (rarity theory);

2) regarding manufacturers of resort and recreational services (theory of production costs);

3 ) in terms of value for money, utility and price (relative utility theory);

4) to maximize the market value of business owners' capital (the concept of value-based management);

5) resort business provides benefits to all stakeholders (consumers theory): consumers, employees, managers, suppliers, investors, entrepreneurs, public servants, territorial community, etc.

An important attribute of market exchange, the basis for determining the profit of manufacturers (sellers) of resort and recreational services, costs of consumers (buyers), a form of expression of market interaction between them is price. Given the non-territorial nature of the production of resort and recreational services, the price acts as a carrier of added value, a means of realizing the business interests of entrepreneurs in the market.

The offer of resort and recreational services in Ukraine should attract the attention of foreign consumers at competitive prices, especially if they are designed in accordance with the domestic market demand and purchasing power of the local population. In this regard, the potentially low tourist costs associated with wellness at Ukrainian resorts may be considered as an attractive factor for foreign tourists.

Figure 1 illustrates the differentiation of the average cost of wellness tourism in calculating per consumer in Ukraine compared to $18 \mathrm{EU}$ countries, Switzerland and Turkey. This indicator is calculated as the ratio of the volume of income from wellness tourism to the number of domestic and international tourists - consumers of health services in a particular country. 


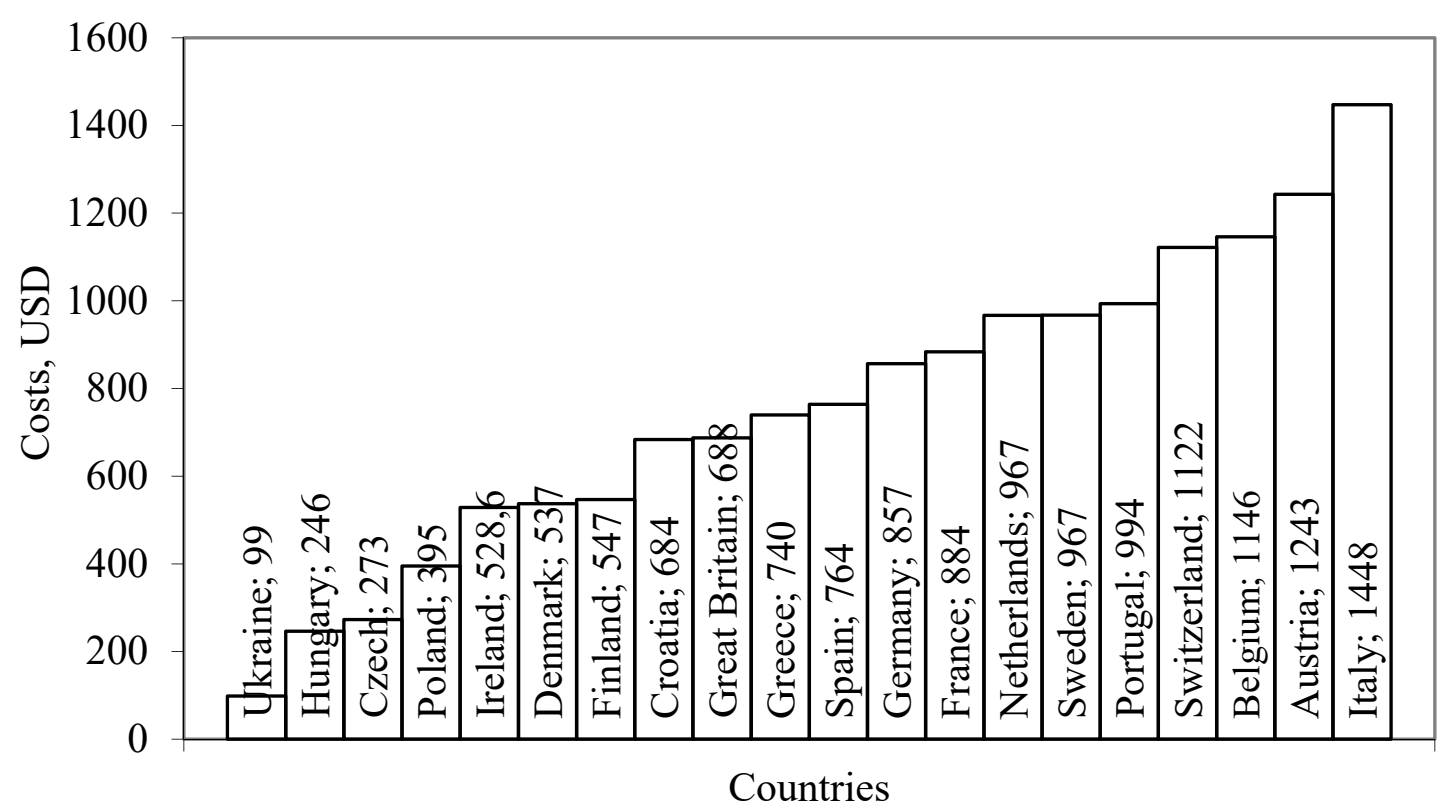

Figure 1 -Costs of wellness tourism in the calculation

Per one consumer in European countries [3, p.17].

The volume of aggregate expenditures of consumers of resort and recreational services on a countrywide scale is determined by the factors of attraction to the resort recreation of the local population and persons who arrived in the resort locality with different tourist motivation. In addition, the consumption of resort and recreational services and their associated costs depend on certain events, phenomena and processes that disturb the market conditions and, accordingly, cause its dynamics both in the direction of economic recovery and in the direction of recession.

Prices for resort and recreation services determine the structure and dynamics of tourist flows are a tool of redistribution of money from health tourism between countries, an important factor for investment mobility. Therefore, due consideration should be given to the development of the state's pricing policy in the market of resort and recreational services.

In Ukraine, the implementation of the state pricing policy, conducting an economic analysis of the level and dynamics of prices, developing and submitting proposals for the formation and implementation of the state pricing policy in accordance with the Law of Ukraine «On Prices and Pricing» of 21.06.2012 № 5007VI rely on the central executive body implementing state pricing policy [18].

Resolution No. 442 of the Cabinet of Ministers of Ukraine «On Optimization of the System of Central Executive Bodies» of 10.09.2014 eliminated the State Inspectorate for Price Control, and its functions of monitoring the dynamics of prices (tariffs) in the consumer market are entrusted to the State Statistics Service [9].

State supervision and control over pricing in the market of resort and recreational services is carried out by bodies of the state fiscal service, control over 
compliance with budget legislation; state control over compliance with the legislation on protection of economic competition. State regulation of prices in the conditions of formation of socially oriented market economy should be directed on protection of the national producer, development of competition.

According to current practice, manufacturers of resort and recreational services, wholly or partly funded by state or local budgets, may purchase medicines and medical devices at prices that do not exceed the level of declared changes in wholesale and retail prices, including duties, value added tax and marginal supply and trade (retail) allowances [10].

At the level of administrative-territorial entities of regional scale, the state authorities are empowered to set tariffs for paid services that provide medical and preventive state and communal healthcare institutions [12].

Formation of unified instruments of tariff-price regulation of the activity of manufacturers of resort and recreational services, regardless of their form of ownership and features of budget financing, will promote market competition between them, elimination of discrepancy of qualitative price characteristics of products and services of medical and health purpose which have arisen as a result of.

Features of functioning of the market of resort and recreational services are distinguished by the instruments of state regulation of prices by which the state can carry out social policy in the system of public health protection. The possibility of their application should be considered based on the ratio of the demand for spa and recreational services and the real needs in the resort rehabilitation, treatment and health of the population.

In Ukraine, the experience of tax regulation of prices for resort and recreational services is gained. In particular, the following tools were used to reduce the cost of spa treatment:

- The Cabinet of Ministers of Ukraine approved the lists of sanatorium-resort establishments whose operations for the sale of services, to which the sanatorium-resort treatment and rest of children were not subject to VAT, periodically amended it [11].

- Recreational establishments by types that did not pay VAT were established in the normative order: children's health camps (towns, complexes) of all types, including health camps for orphans; extracurricular health camps; children's health resorts of sanatorium type; labor and recreation camps; recreation camps for high school students and student youth; recreation camps with daily relocation on the basis of schools, boarding, preschool, extracurricular, cultural, educational and sports facilities; specialized camps (tourist, health, sports, gifted children, etc.); summer cottages for summer rehabilitation of preschool children; boarding houses, recreation centers, sanatoriums-preventive hospitals, health resorts of enterprises, institutions, organizations and trade unions (subject to the organization of specialized changes for children). 
- Exemption from taxation on operations for the provision of medical services to health care institutions, the provision of services to rehabilitation institutions for disabled people and children with disabilities (except for massage to promote the health of the adult population, posture correction, etc.).

- Supply of rehabilitation services to disabled persons, children with disabilities, sanatorium-spa treatment, rehabilitation and rest on the territory of Ukraine of persons under 18 years of age, disabled persons, and disabled children [5].

The problem of rising prices for medicines also imposes a negative mark on the formation of the cost of resort rehabilitation and treatment of the population, and its solution is in line with the implementation of the foreign experience of reference pricing, the use of the practice of government fixed prices for medicines, systems of tariffs for medical services in accordance with basic standards of medical care.

There is a situation when the spontaneous nature of pricing does not contribute to improving the quality of resort and recreational services, and the state's pricing policy in the resort and recreation sphere does not provide the generation of economic incentives to strengthen the internal market and the formation of export potential of resort and recreational services. This means that the mechanism of state regulation of prices for resort and recreational services needs improvement.

If the overall price increase is combined with the process of reducing the purchasing power of consumers and outstrips it in the dynamics, then only in the shortterm aspect can we expect positive structural changes due to import substitution of resort and recreational services. The criticality of this situation is measured by the market parameters of the purchasing power of national consumers, who express their willingness to meet the need for health restoration through self-financing of resort and recreation within the country.

However, due attention should be paid to other important factors that comprehensively influence the formation of the value chain of the resort and recreational service and the establishment of market prices for resort and recreational services.

Fiscal regulation of the resort and recreation services market should provide incentives to activate entrepreneurial activity and accumulate financial resources of the state to solve socio-economic goals. At the same time, the tax regulation of the resort and recreational activity is limited by administrative approaches to expanding the tax base by attracting the corporate sector and informal resort service to taxation. It is necessary to clarify the list of privileges and base for determining the tourist fee («the cost of the whole period of stay (overnight stay)»), Article 268.4.1. «Resort tariff»), which will allow to differentiate tax payments, and provided they accumulate in the system of local budgets to use financial resources for the appropriate purpose: «development of hospitality and tourism» and «development of resorts». 
Thus, modernization of the mechanism of state regulation of the market of resort and recreational services on the basis of stimulation of free pricing, competition, socially oriented entrepreneurship is an important prerequisite for the implementation of state policy aimed at human capital development, strengthening national security, comprehensive solution of socio-economic problems, improvement of public welfare and health of the nation.

Conclusion. Based on the study of the process of formation of the mechanism of state regulation of the market of resort and recreational services in Ukraine, the presence of several divergent vectors of state policy regarding the system of selfregulation (excessive tax pressure / lack of taxation, regulatory prohibition of privatization of health and recreation facilities / and hidden establishments of it), as well as the contradictory coexistence of outdated and new concepts, forms and methods of state influence (establishment of territorial regime and definition of zones of regulated recreation / tools of sustainable development of resort destinations), which negatively reflected on the impact of economic and social policy in the pricing of the resort and recreational services.

Due to the need to increase the effectiveness of state social policy in the market of recreational and recreational services in the context of human capital development, the practice of formal compensatory payments for non-provided social services of citizens, which are classified as preferential categories, needs to be replaced by real targeted subsidization and reimbursement of consumer spending - recreational services. Fixing the necessary minimum of resort and recreational services in the consumer basket and forming a Ukrainian consumer budget, taking into account the norm of annual rest and recovery, is consistent with the directions of improvement of social policy of Ukraine in the context of EU integration.

\section{REFERENCES}

1. Chernysh, I. (2014). Formuvannya antykryzovoyi polityky derzhavy u turyzmi[Formation of anti-crisis policy of the state in tourism]. Monohrafiya. Poltava ASMI[in Ukrainian].

2. Global Wellness Economy Monitor (2018).Global Wellness Institute. Retrieved from https://globalwellnessinstitute.org/industry-research/2018-globalwellne sseconomy-monitor/.

3. Humeniuk, V. (2017). Derzhavne rehulyuvannya rynku kurortnorekreatsiynykh posluh [State regulation of resort and recreational services market]. Doctor of Science thesis. Kyiv [in Ukrainian].

4. Humeniuk,V. (2018)Financial nature of resort multiplierFinancial and credit activity: problems of theory and practice. Vol. 2. Is. 25. P. 417-423, DOI: 
https://doi.org/10.18371/fcaptp.v2i25.136501 Retrieved from: http://fkd.org.ua/article/ view/136501

5. Kodeks Ukrayiny «Podatkovyy kodeks Ukrayiny» (2010) № 2755-VI vid 02.12.2010 [Code of Ukraine «Tax Code of Ukraine»]. (n.d.) zakon.rada.gov.ua. Retrieved from http://zakon2.rada.gov.ua /laws/ show/2755-17 [in Ukrainian]

6. Mazaraki,A., Lagutin, V.(2004) Domestic market of Ukraine in an unstable global economy. Herald of Kyiv National University of Trade and Economics. Vol. 6 Is. 98. P. 9-24.

7. Melnychenko, S. (2013) Health resort enterprises: between stagnation and modernization. Herald of Kyiv National University of Trade and Economics. Vol. 6. P. 57-67.

8. Mochernyy, S. (2002). Ekonomichna entsyklopediya: u tr'okh tomakh [Economic encyclopedia in three volumes]. Kyiv: Vydavnychyy tsentr «Akademiya» [in Ukrainian].

9. Postanova Kabinetu ministriv Ukrayiny»Pro optymizatsiyu systemy tsentral'nykh orhaniv vykonavchoyi vlady» № 442. (2014). [Resolution of the Cabinet of Ministers of Ukraine «On the Optimization of the System of Central Bodies of Executive Power»]. (n.d.) zakon.rada.gov.ua. Retrieved from http://zakon5.rada. gov.ua/laws/show /442-2014-\%D0\%BF [inUkrainian].

10. Postanova Kabinetu ministriv Ukrayiny»Pro referentne tsinoutvorennya na likars'ki zasoby ta vyroby medychnoho pryznachennya, shcho zakupovuyut'sya za koshty derzhavnoho ta mistsevykh byudzhetiv» № 240 (2014) [Resolution of the Cabinet of Ministers of Ukraine «On reference pricing for medicines and medical devices purchased from the state and local budgets»]. (n.d.) zakon.rada.gov.ua. Retrieved from http://zakon0.rada.gov.ua /laws/show/240-2014-\%D0\%BF [in Ukrainian].

11. Postanova Kabinetu ministriv Ukrayiny «Pro pereliky sanatorno-kurortnykh zakladiv i zakladiv vidpochynku, operatsiyi z prodazhu putivok do yakykh na sanatorno-kurortne likuvannya ta vidpochynok ditey ne pidlyahayut' obkladennyu podatkom na dodanu vartist'» No 835.(1997). [Resolution of the Cabinet of Ministers of Ukraine «On the lists of health resorts and recreation establishments, operations for the sale of vouchers to which the value added tax is not subject to value added tax for sanatorium treatment and recreation of children»]. (n.d.) zakon.rada.gov.ua. Retrieved from http://zakon4.rada.gov.ua/laws/ show/835-97-\%D0\%BF [in Ukrainian].

12. Postanova Kabinetu ministriv Ukrayiny»Pro vstanovlennya povnovazhen' orhaniv vykonavchoyi vlady ta vykonavchykh orhaniv mis'kykh rad shchodo rehulyuvannya tsin (taryfiv)»No1548 (1996). [Resolution of the Cabinet of Ministers of Ukraine «On establishing the powers of executive authorities and executive bodies of city councils to regulate prices (tariffs)»]. (n.d.) zakon.rada.gov.ua. Retrieved from http://zakon3.rada.gov.ua/ laws/show/1548-96-\%D0\%BF [in Ukrainian]. 
13. Szeged Consensus Statement on Balneology and Health Resort Medicine (2015)Europeanspasassociation.Retrieved fromhttp://www.espa-ehv.eu/spamedicine/

14. Tyshchenko, O. (2016). Kurortno-rekreatsiyna sfera Ukrayiny: stan, vtraty, shlyakhy sanatsiyi [Resort and recreation sphere of Ukraine: condition, losses, ways of sanation]. Ekonomika i suspil'stvo, 6, 93-100. Retrieved from http://www.economy andsociety.in.ua/journal/6_ukr/16.pdf [in Ukrainian].

15. Unwto Tourism Highlights: 2018 Edition. (2018). World Tourism Organization. Madrid, DOI: https://doi.org/10.18111/9789284419876. Retrieved from https://www.e-unwto.org/doi/pdf/10.18111/9789284419876.

16. Ushenko, N. (2015). Antykryzova paradyhma vykorystannya potentsialu suchasnoho turyzmu [Anti-crisis paradigmofusing the potential of modern tourism] Visnyk Berdyans'koho universytetu menedzhmentu i biznesu, 3, 29-33. Retrieved from http://old.bumib.edu.ua/sites/default/files/visnyk/7_8.pdf [in Ukrainian].

17. Woodruff R., Gardial S. (1996). Know Your Customer: New Approaches to Understanding Customer Value and Satisfaction. Cambridge Massachusetts. Backwell Publishers Inc., $360 \mathrm{p}$.

18. Zakon Ukrainy «Pro tsiny i tsinoutvorennya» № 5007-VI. (2012). [Law of Ukraine «Onpricing and pricing»]. (n.d.) zakon.rada.gov.ua. Retrieved from https://zakon.rada.gov.ua/laws/show/5007-17 [in Ukrainian]. 